\title{
Construction of a Chimeric Plasmid in Bacillus subtilis
}

\author{
Takayuki Hoshino, Takeshi Uozumi and Teruhiko BePPU \\ Department of Agricultural Chemistry, The University of Tokyo, \\ Tokyo 113, Japan \\ Received May 6, 1980
}

\begin{abstract}
Staphylococcal plasmids pTP4 (2.7 megadaltons encoding resistance to chloramphenicol) and pTP5 (2.6 megadaltons encoding resistance to tetracycline), which replicate and express resistance in B. subtilis, were found to cut by HindIII endonuclease respectively at a single site and three sites. A chimeric plasmid pTA1245 (4.1 megadaltons) was constructed from pTP4 and pTP5 by HindIII digestion and ligation with $E$. coli DNA ligase. pTA1245 expresses resistances to chloramphenicol and tetracycline in B. subtilis, and pTA1245 is amplified in the presence of tetracycline. A physical map of pTA 1245 was constructed.
\end{abstract}

Recently, certain antibiotic resistant plasmids originally detected in Staphylococcus aureus have been transformed into $B$. subtilis. $^{1{ }^{25}}$ These plasmids could be usuable as molecular cloning vectors in $B$. subtilis. We have also tried to construct a molecular cloning system in $B$. subtilis, and have already obtained a useful host strain $B$. subtilis RM $125^{61}$ which lost its restriction and showed high efficiency in transformation with heterologous DNAs of Bacillus species. "This paper reports construction of a chimeric plasmid presumably usuable as a cloning vector in $B$. subtilis.

\section{MATERIALS AND METHODS}

Bacterial strains and plasmids. B. subtilis RM125 ( $\arg _{15}$, leu $\mathrm{A}_{8}, h s r \mathrm{M}, h s m \mathrm{M}$ ) was used as a recipient strain in this experiment. $B$. subtilis LMAH761222 (leu $^{-}$, metB ${ }^{-}$, ade ${ }^{-}$, his ${ }^{-}$) strains carrying pTP4 and pTP5, respectively, were kindly supplied by Dr. Megumi Kono (Tokyo College of Pharmacy).

Media. NY medium used for bacterial growth was described previously. ${ }^{6)}$ Media for preparation of competent cells of $B$. subtilis were prepared as described." Antibiotic concentration used for selection were $10 \mu \mathrm{g} / \mathrm{ml}$ for both chloramphenicol $(\mathrm{Cm})$ and tetracycline $(\mathrm{Tc})$.

Isolation and characterization of plasmid DNA. Plasmid DNA from $B$. subtilis was isolated by the method of Tanaka et al. ${ }^{8 /}$ Characterization of plasmid DNA and plasmid DNA fragments were performed by electrophoresis on vertical $0.8_{\%}^{\circ}$ agarose (Wako Pure Chemical) gels. Restriction endonucleases HindIII, EcoRI and BamI were purchased from Boehringer Mannheim. BsuG was prepared as previously described. ${ }^{91}$ Sall was prepared by the method of Arrand ef al. ${ }^{10}$ )

Transformation of plastiid DNA. Frozen competent cells of $B$. subtilis RM125 were prepared as described. ${ }^{11}$ DNA uptake and incubation for expression were performed as described previously. ${ }^{\text {s }}$

Ligation procedures. One $\mu \mathrm{g}$ of pTP4 DNA and $3 \mu \mathrm{g}$ of pTP5 DNA were separately digested with Hindlll for 90 min at $37^{\circ} \mathrm{C}$. pTP4 DNA was completely digested and pTP5 DNA was partially digested in this condition. Digested DNAs were mixed and precipitated by two volumes of cold ethanol and dissolved in $100 \mu$ of ligation buffer. ${ }^{12)} E$. coli DNA ligase $(20 \mu \mathrm{l})$ which was prepared by the method of Modrich et al. ${ }^{131}$ was added to the mixture. After the mixture was incubated at $11^{\circ} \mathrm{C}$ for $48 \mathrm{hr}$, ligated DNA was precipitated by cold ethanol and dissolved in TES ( $50 \mathrm{~mm}$ Tris, $10 \mathrm{~mm} \mathrm{NaCl}, 5 \mathrm{~mm}$ EDTA, $\mathrm{pH} 7.5$ ). This solution was mixed with competent cells of $B$. subtilis RM125 for transformation.

Biohazard procedures. This experiment was carried out under $P 1$ containment level as specified by the Ministry of Education, Science and Culture of Japan.

\section{RESULTS}

Isolation and analysis of chimeric plasmid

Plasmids pTP4 $(1 \mu \mathrm{g})$ and pTP5 $(3 \mu \mathrm{g})$ were separately digested with HindIII, mixed and treated with $E$. coli DNA ligase. After in- 


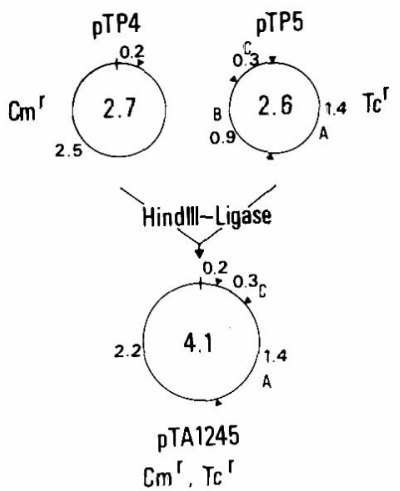

FIG. 1. Construction of pTA1245.

Plasmids pTP4 and pTP5 were digested with HindIII, followed by ligation with $E$. coli DNA ligase. The ligation mixture was used to transform $B$. subtilis RM125. A plasmid extracted from a $\mathrm{Tc}^{\mathrm{r}} \mathrm{Cm}^{\mathrm{r}}$ transformant was named as pTA1245. The structure of pTA1245 was determined by following experiment (Figs. 2 and 3 ). Symbols (-) EcoRI site; ( ) HindIII site.

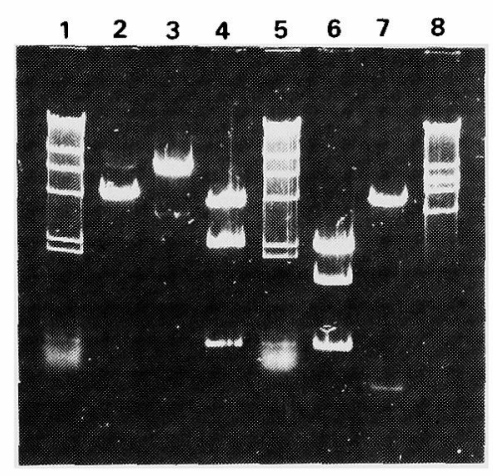

FIG. 2. Cleavage Patterns of pTA1245.

Plasmid DNAs were digested with restriction endonucleases. Digested fragments were analyzed by agarose gel electrophoresis $(0.8 \%$ agarose gel, $80 \mathrm{~V}, 2 \mathrm{hr})$. 1 and 5, HindIII-digested $\lambda \mathrm{DNA}$ fragments as the standards of molecular weights; 2 , pTP4 DNA digested with EcoRI; 3, pTA1245 DNA digested with EcoRI; 4, pTA1245 DNA digested with HindIII; 6, pTP5 DNA digested with HindIII; 7, pTP4 DNA digested with EcoRI and HindIII; 8, EcoRI-digested $\lambda$ DNA.

cubation at $11^{\circ} \mathrm{C}$ for $48 \mathrm{hr}$, some ligation products were observed by agarose gel electrophoresis (data not shown). The mixture was used to transform B. subtilis RM125. In this experiment, only one $\mathrm{Cm}$ resistant $\left(\mathrm{Cm}^{\mathrm{r}}\right)$ and $\mathrm{Tc}$ resistant $\left(\mathrm{Tc}^{\mathrm{r}}\right)$ transformant was obtained. The plasmid pTA1245 DNA isolated from this transformant was digested with HindIII and EcoRI restriction endonucleases. As shown in Fig. 1 and Fig. 2, pTA1245 was digested with EcoRI at only one site, and 4.1 megadaltons fragment was observed. HindIII digestion of pTA1245 produced $A$ and C fragments of pTP5 and 2.4 megadaltons fragment. This 2.4 megadaltons fragment seemed to be a deleted fragment of pTP4, and this was designated as pTP4'. This deleted plasmid pTP4' was often obtained after transformation of $B$. subtilis RM125 with pTP4 native DNA.

Plasmids pTP4, pTP5 and pTA1245 DNAs were not digested by BamI, BsuG and $S a l \mathrm{I}$ restriction endonucleases.

In order to investigate the orientation of pTP4', pTP5-A and pTP5-C fragments in pTA1245, pTA1245 was linearlized with EcoRI and digested further with HindIII. HindIII digestion was performed at $22^{\circ} \mathrm{C}$, and partial digestion products were analyzed by agarose gel electrophoresis. Because a fragment of 0.5 megadaltons was observed at $20 \sim 45 \mathrm{~min}$ of digestion, the orientation of pTA1245 was determined as Fig. 3.

\section{Characterization of pTA1245}

Covalently closed circular pTA1245 DNA was used to transform B. subtilis RM125. $\mathrm{Cm}^{\mathrm{r}}$, $\mathrm{TC}^{r}$ transformants were obtained at an efficiency of about $10^{4}$ transformants/ $\mu \mathrm{g}$ DNA. This efficiency was almost the same as that of transformation with pTP4 or pTP5 plasmid DNA $\left(10^{3} \sim 10^{4}\right.$ transformants $/ \mu \mathrm{g}$ DNA).

It was reported that tetracycline resistant plasmid pTP5 was amplified when Tc was added to the growth medium, and the ratio of the plasmid DNA to chromosomal DNA reached $38 \sim 68 \%{ }^{14)}$ In order to investigate the effect of Tc on the copy number of pTA1245, plasmid DNA prepared from $B$. subtilis RM125 (pTA1245) grown under four conditions (no drugs, presence of $\mathrm{Cm}$, presence of $\mathrm{Tc}$, and presence of $\mathrm{Cm}$ and $\mathrm{Tc}$ ) were examined by agarose gel electrophoresis. As shown in Fig. 4, the copy number of pTA1245 was increased by Tc treatment. This fact shows that pTA1245 is replicated under control of 
01020304590

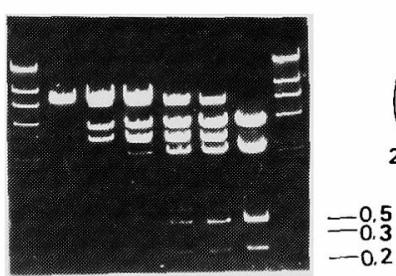

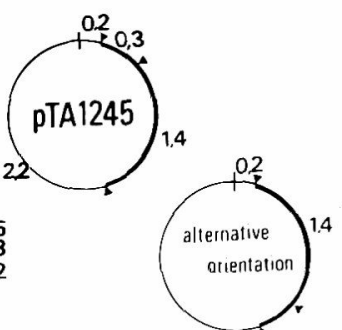

FIG. 3. Partial Digestion of pTA1245.

Plasmid pTA1245 DNA was linearlized by EcoRI digestion. This linear DNA was digested further with HindIII at $22^{\circ} \mathrm{C}$.

Symbols: (-) EcoRI site; (\) HindIII site.

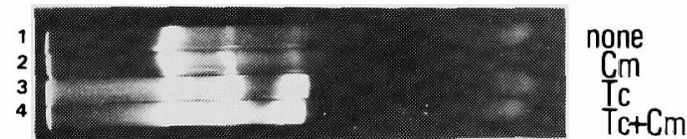

FIG. 4. Effects of Drugs on Copy Number of pTA 1245.

B. subtilis RM125 was grown in $10 \mathrm{ml}$ of $\mathrm{NY}$ medium under four conditions (1, no drugs; 2 , presence of $10 \mu \mathrm{g} / \mathrm{ml}$ of $\mathrm{Cm} ; 3$, presence of $10 \mu \mathrm{g} / \mathrm{ml}$ of $\mathrm{Tc} ; 4$, presence of $\mathrm{Cm}(10 \mu \mathrm{g} / \mathrm{ml})$ and $\mathrm{Tc}(10 \mu \mathrm{g} / \mathrm{ml}))$. Cleared lysates were prepared from these cultures and examined by agarose gel electrophoresis. The copy number of pTA1245 increased when Tc was added to the growth medium.

pTP5 replicator in the presence of Tc.

\section{DISCUSSION}

In this study, a chimeric plasmid pTA1245 constructed from pTP4 and pTP5 by "HindIII-ligase method" was found to replicate and inherit stably in B. subtilis. This result indicates that pTP4 and/or pTP5 can be vector(s) of molecular cloning in B. subtilis. Especially, it was found that the replicator of pTP5 is active in the chimeric plasmid pTA 1245, and it is highly amplified in the presence of tetracycline. The plasmids pTP5 and pTA1245 will be useful vectors for cloning of foreign DNA in $B$. subtilis, because of the amplifiability.

Molecular cloning vectors are required to have high transforming efficiencies. The transforming efficiencies of pTA1245 and pTP5 are about $10^{4}$ transformants $/ \mu$ g DNA. This ratio is not sufficient, because cloning procedures consist of many steps those decrease transforming efficiencies of plasmids. So it is necessary to increase the transforming efficiencies of vector plasmids.

\section{REFERENCES}

1) S. D. Ehrlich, Proc. Natl. Acad. Sci. USA, 74, 1680 (1977).

2) S. D. Ehrlich, ibid., 75, 1433 (1978).

3) K. M. Keggins, P. S. Lovett and E. J. Duvall, ibid., 75, 1423 (1978).

4) T. J. Gryczan and D. Dubnau, ibid., 75, 1428 (1978).

5) T. J. Gryczan, S. Contente and D. Dubnau, J. Bacteriol., 134, 318 (1978).

6) T. Uozumi, T. Hoshino, K. Miwa, S. Horinouchi, T. Beppu and K. Arima, Molec. Gen. Genet, 152, 65 (1977).

7) T. Hoshino, T. Uozumi, T. Beppu and K. Arima, Agric. Biol. Chem., 44, 621 (1980).

8) T. Tanaka, M. Kuroda and K. Sakaguchi, J. Bacteriol., 129, 1487 (1977).

9) T. Hoshino, T. Uozumi, S. Horinouchi, A. Ozaki, T. Beppu and K. Arima, Biochim. Biophys. Acta, 479. 367 (1977).

10) J. R. Arrand, P. A. Myers and R. J. Roberts, J. Mol. Biol., 118, 127 (1978).

11) D. Dubnau and R. Davidoff-Abelson, ibid., 56, 209 (1971).

12) K. Timmis, F. Cabello and S. N. Cohen, Proc. Natl. Acad. Sci. USA, 72, 2242 (1975).

13) P. Modrich, Y. Anraku and I. R. Lehman, J. Biol. Chem., 248, 7495 (1973).

14) M. Kono, M. Sasatsu and H. Hamashima, Microbios Letters, 5, 55 (1978). 